\title{
Onset vs. recovery in the aversive effects of electroconvulsive shock
}

\author{
R. GERRY DAWSON AND GORDON T. PRYOR \\ STANFORD RESEARCH INSTITUTE
}

\begin{abstract}
Abstraet
When the place of administration and of recovery from a series of electroconvulsive shock (ECS) treatments was systematically varied in a two-compartment box, groups of shocked rats spent significantly less time in the compartment where ECS was administered than did controls. Place of recovery appeared to be unimportant and no indications of amnesia resulting from the ECS were observed.
\end{abstract}

\section{Problem}

After repeated ECS treatments, rats develop an aversion for the situation in which ECS is administered (Coons \& Miller, 1960). Presumably, some stimuli in the environment can become linked with some aspects of the ECS, such as generalized fear (Coons \& Miller, 1960) or fractional responses (Adams \& Lewis, 1962). To determine which cues take on aversive characteristics-those in the environment where shock is administered or those in the environment where convulsion and subsequent recovery occur-shock and recovery were systematically varied in two different locations. Additionally, to gain information about the amnesic properties of ECS and their possible interaction with the aversive properties, some Ss were allowed to find water in one of the locations prior to ECS.

\section{Apparatus}

The test device was a wooden box (16 in $\times 8$ in $\times 8$ in), divided by a sliding center partition. One compartment was white, with a wire mesh floor and a black-striped plexiglas top. The other was flat black, with a wooden floor and an opaque plexiglas top. Different intensities of illumination were provided by a blue and a yellow 6-w bulb, respectively. The apparatus was located in a dark, quiet room.

\section{Subjects}

Seventy-two male Long-Evans rats (pigmented), 70$90 \mathrm{gm}$, were housed in pairs and maintained on a 48-hr. water deprivation schedule. Food was given ad lib throughout the experiment.

\section{Procedure}

Temporally, the experiment was carried out in two stages, Groups 1-5 constituting the first stage and Groups 6-12, the second. All groups had six Ss.

At the beginning of the experiment, all Ss were deprived of water for $48 \mathrm{hr}$. and then tested for $5 \mathrm{~min}$. in the apparatus with the partition raised, to establish initial preferences. Water was withheld during this and subsequent preference tests.
Training trials began after a 24-hr. rest, according to the design in Fig. 1. S was placed in Compartment $\mathrm{A}$ for $5 \mathrm{~min}$. To avoid confounding the initial preferences, half of the Ss were given experience in the preferred compartment, half in the non-preferred compartment. $S$ was then removed momentarily and deposited in whichever compartment the ECS or sham procedure was to be carried out.

Ear electrodes smeared with electrolyte paste were attached while $S$ was facing the light in the appropriate compartment. Maximal seizures were induced, using a constant current stimulator, by a 60-cycle a. c. current of $0.2-\mathrm{sec}$. duration, which was raised in $10-\mathrm{ma}$ increments from 50 to $70 \mathrm{ma}$ during the experiment. $\mathrm{S}$ was removed from the apparatus immediately after shock, the ear clips were removed, and $\mathrm{S}$ was replaced in the appropriate recovery compartment for $5 \mathrm{~min}$. before being returned to the home cage. Sham procedure was identical except that no current was delivered. All Ss were given water for $45 \mathrm{~min}$. in their home cages, $2 \mathrm{hr}$. after each training trial. Each $\mathrm{S}$ received one trial every $48 \mathrm{hr}$. for nine trials.

The two control groups were not given training in the apparatus. The temporal control group was handled only; the treatment control group was given ECS in a neutral, undivided box at the same time intervals as training was given to other groups.

Twenty-four hours after the seventh through ninth training trials, Ss were given another preference test, identical to the first one.

\begin{tabular}{|c|c|c|c|c|c|}
\hline \multirow{2}{*}{ Treatment } & \multirow{2}{*}{$\begin{array}{c}\text { Compartment } \\
\text { in which } \\
\text { Treatment } \\
\text { Administered }\end{array}$} & \multicolumn{2}{|c|}{$\begin{array}{l}\text { Recovery } \\
\text { in Same Side }\end{array}$} & \multicolumn{2}{|c|}{ Recovery } \\
\hline & & $\begin{array}{l}\text { Water } 1 \\
\text { Present }\end{array}$ & $\begin{array}{l}\text { Water } \\
\text { Absent }\end{array}$ & $\begin{array}{c}\text { Water } \\
\text { Present }\end{array}$ & $\begin{array}{l}\text { Water } \\
\text { Absent }\end{array}$ \\
\hline \multirow{2}{*}{ ECS } & A & Group 1 & Group 2 & Group 6 & Group 7 \\
\hline & B & Group 3 & Group 4 & Group 8 & Group 9 \\
\hline \multirow[t]{2}{*}{ Sham ECS } & A & Group 5 & \multirow{2}{*}{\multicolumn{3}{|c|}{$N=6$ For All Groups }} \\
\hline & B & Group 10 & & & \\
\hline
\end{tabular}

Group 11 - Temporal Control

Group 12 - Treatment Control

1 Present or absent during 5-min period in Compartment $A$ prior to treatment.

Fig, 1. Experimental design. 


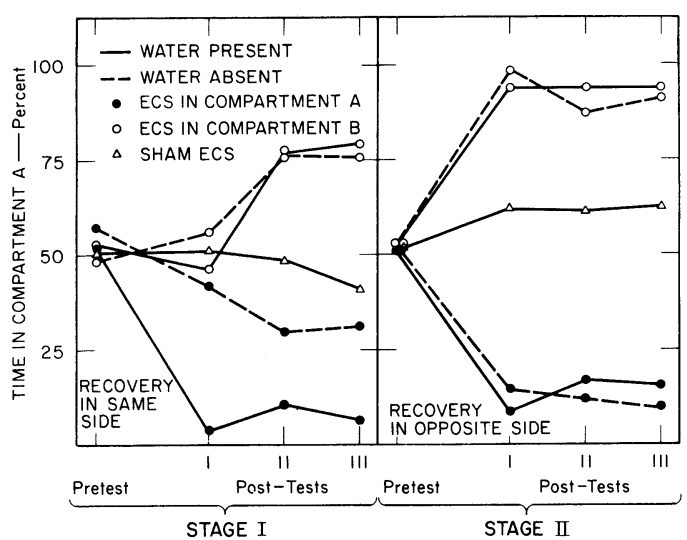

Fig. 2. Percentage of time spent by each group in Compartment $A$.

\section{Results and Diseussion}

No differential effects due to initial preference were found for any of the groups. Subsequent analyses were done ignoring this variable. The mean percentage of time spent in Compartment $\mathrm{A}$ by each group on each of the preference tests is shown in Fig. 2. Groups that received ECS spent less time in the compartment where ECS was administered than did control or sham ECS groups. Analysis of variance of the data indicated that these trends were not due to chance $(p<.001)$. The latter two groups did not change their initial preference. There were no significant effects due to the presence or absence of water, or the place of recovery.

The results of this experiment clearly suggest that the aversive aspects of ECS are predominantly confined to the onset of shock. The absence of any effect due to the presence or absence of water in the ECS groups cannot be interpreted as amnesia for the positive cues associated with drinking, since sham ECS groups showed no preference change toward the compartment in which water was available.

It is possible that internal aversive cues arising during convulsion and subsequent recovery do not become associated with the stimuli in the immediate environment. This may be due to some inability of the nervous system to accept and/or integrate new information within the 5-min. recovery period following ECS. Alternatively, the aversive cues in the postECS state may perseverate and become associated with the preshock environment.

\section{References}

Adams, H. E., \& Lewis, D. J. Retrograde amnesia and competing responses. J. comp. physiol. Psychol., 1962, 55, 302-305.

Coons, E. E., \& Miller, N. E. Conflict versus consolidation of memory traces to explain "retrograde amnesia" produced by ECS. J. comp. physiol. Psychol., 1960, 53, 524-531.

\section{Note}

1. This research was supported by Contract Nonr-2993(00) between the Office of Naval Research and Stanford Research Institute. 